\title{
Urban Structure Matters, Even in a Small Town
}

\author{
Petter Næss, Aalborg University, Fibigerstraede 11, DK-9220 Aalborg, Denmark. E-mail \\ petter@i4.auc.dk \\ Ole B. Jensen, Aalborg University, Fibigerstraede 11, DK-9220 Aalborg, Denmark. E- mail \\ obj@i4.auc.dk
}

\begin{abstract}
A recent study in Frederikshavn, Denmark, shows that urban structural variables influence travel behavior also in a small town of around 30000 inhabitants. As one might expect, socioeconomic and attitudinal factors play a role for the respondents' traveling patterns. But also when controlling for these factors and a range of other potential explanatory variables, we find clear relationships between urban structural characteristics and travel activity. These relationships exist across most subgroups of the population. The statistical relationships found between urban structure and travel behavior are confirmed in qualitative interviews. The distance from the residence to the downtown area is a key factor influencing the accessibility to a number of facility types. These differences in accessibility result in corresponding differences in the actual traveling distances and modal split.
\end{abstract}

\section{Introduction}

In several countries national land use policies in recent years have aimed at trying to limit the growth in urban transport, in particular automobile use, by means of spatial planning. The underlying assumption behind these policies is a belief that dense and concentrated cities can reduce the needs for travel by limiting the distances between residences, workplaces and service facilities, and also facilitate the use of public and non-motorized means of transport.

However, the "spatial planners' logic" on which these policies are based, has been repeatedly challenged by other groups of professionals, in particular economists, but increasingsly also sociologists and other social scientists. Many observers claim that the proximity or distance between the different facilities of an urban area is no longer important. The early empirical studies showing correlation between urban form variables and gasoline consumption (e. g. Newman and Kenworthy, 1989) have been criticized for not taking into account socioeconomic factors suspected to be the real determinants of the observed differences in transportation behavior. Some later studies have included a number of socioeconomic variables along with urban structural characteristics, showing that the relationships between the latter and travel behavior pertain even when controlling for socioeconomic features of the travelers. Yet, these results have also been questioned: Maybe those individuals who prefer to live in the neighborhoods where the average traveling distances are low and car usage modest, have different attitudes to traveling than their counterparts in more car-based neighborhoods, and maybe these attitudes and lifestyles, rather than geographical location per se, are the causes of the observed differences in transport behavior? Moreover, some critics call attention to the fact that statistical correlation, even with multivariate control, can never establish whether a causal relationship exists between urban structure and travel behavior (Handy 1996, Røe 1999). Much of mainstream research on the topic is also surprisingly silent about the theoretical reasons why urban structure could at all be expected to influence travel behavior. 
Thus, in a recent book on sustainable urban development, Frey (1999) concludes that there are no unambiguous data indicating that a compact or a more dispersed urban structure contributes to a higher or a lower energy use. In a similar vein, a governmental representative, apparently seeking support for a relaxation of the Dutch urban containment policies, tried to persuade the invited speakers of the conference "Land Use and Travel Behavior" in Amsterdam in 2000 to join his conclusion that the relationships between urban structure and travel are "weak" and "uncertain".

The study dealt with in this paper has been designed with the above-mentioned doubts and criticisms against the "obvious" assumptions of the urban planning tradition as an important background:

- The study includes urban form variables as well as socioeconomic and attitudinal characteristics of the travelers

- A broader range of urban structural characteristics has been investigated than what is usually the case in this type of studies

- The traditional quantitative travel survey approach has been combined with qualitative interviews in order to illustrate some of the more detailed mechanisms through which urban structure affects travel behavior.

In addition, the study deals with a settlement size where the relationship between land use and travel behavior has hardly been investigated before: a municipality of 35000 inhabitants, of which 26000 in the main town and most of the remaining 9000 distributed between a handful of smaller villages. The investigated town, Frederikshavn, is located in Northern Jutland, Denmark, about $60 \mathrm{~km}$ to the north of the regional center of Aalborg.

The paper is structured in five sections: the theoretical point of departure, a presentation of the Frederikshavn case study, the results from the quantitative analysis, the results from the qualitative analysis, and finally the concluding remarks.

\section{Theoretical point of departure}

According to theories of transport geography and transport economy, the travel between different destinations is assumed to be influenced on the one hand by the reasons people may have for going to a place, and on the other hand by the discomfort involved when traveling to this location (Jones, 1978; Beimborn, 1979). Or, in other words, by the attractiveness of the locations and the friction of distance. By creating proximity as well as distance between activities, and by facilitating various modes of traveling, the urban structure makes up a set of incentives facilitating some kinds of travel behavior and discouraging other types of travel behavior. The causes of travel behavior of course also include personal characteristics of the travelers, such as age, sex, income, professional status, as well as their values, norms, lifestyles and acquaintances. The emerging transportation pattern is a result of people's resources, needs and wishes, as modified by the constraints and opportunities given by the structural conditions of society (see Næss and Jensen, 2002, for a more thorough discussion).

The increasing physical mobility of the late modern individual implies that new mobility features (infrastructure, technology innovations etc.) are being merged into an everyday life that for most parts still is identifiable by its routines, repetitions and more or less well established "rhythms" (see, e.g., Lindén \& Carlsson-Kanyama 1998, Giddens 1984,). The transport routine acts of everyday life are embedded within a more or less fixed practice of 
moving between spheres for work, consumption and leisure. This form of physical mobility is characterized by its routinization and thus will be understood as the "scheduled" trips of everyday life. However, symbolic and cultural features attributed to an area may also affect the number of visitors attracted (if not, the phenomenon of tourism would hardly have existed). Many travels are not "scheduled" and as such open to social agents' use of transportation in terms of "constructing" a specific lifestyle (Giddens 1991).

The situation is further complicated by the fact that increased accessibility may create new needs. For example, the increased accessibility facilitated by the shorter average distances between different functions (residences, jobs, service facilities etc.) in dense and concentrated cities, might be utilized by increasing the radius of action to include a wider range of opportunities, rather than by reducing the amount of travel. The multitude of structural and individual factors likely to influence transportation behavior make the study of relationship between land use and transportation a challenging exercise.

\section{Location of residences}

Traditionally, many European cities have had a concentration of workplaces and service functions (particularly civil service, cultural institutions, restaurants, entertainment and specialized stores) in the central parts. In many cities, a wide range of facilities covering the city as a whole or the city region are located in this area. Because of this high accessibility, downtown areas have attracted stores and other service facilities requiring a large population base (Christaller, 1933/1966:49-70). For the same reason, public authorities and agencies are often located in the city center. This concentration of facilities also increases the possibility for visitors to carry out several errands within a small geographic area, which in itself increases the competitiveness of the urban core as a location for retail and other services (Christaller, ibid:43, 105). Moreover, for many types of businesses, a location in the city center may offer so-called agglomeration benefits (Vatne, 1993).

The closer to downtown the residences of such cities are located, the more workplaces and service facilities are likely to be available in the proximity of the dwelling. This also implies that a higher share of the residents will find it acceptable to walk or bike to these destinations instead of using motorized transportation. Moreover, the geographical center of gravity of the housing stock is often situated close to the historical urban core, and the latter is usually also the main node of the public transport system(Nielsen, 2002). Accordingly, insofar as people choose workplaces, leisure activities and acquaintances within the city as a whole, inner-city residents will on average make shorter trips than their suburban counterparts, also when the destinations are located in the outer areas of the city.

Usually, there is neither tradition nor demand for the same densities in peripheral parts of a city as in the inner and central areas. With a higher density of residences and/or workplaces in the local area, the population base for various types of local service facilities will also increase. Hence, the average distance from inner-city dwellings to local service will also be shorter, possibly encouraging some of the residents to make their trips to these facilities by non- motorized modes.

By influencing the distances to downtown facilities, local facilities, as well as non-local, outer-area destinations, the location of the residence relative to the city center could, according to the above line of reasoning, be expected to influence both the residents' traveling distances and their modal choices. In both ways, a central location of residences would contribute to limit the use of energy for everyday traveling purposes. 
As mentioned in the introduction, investigations in a number of towns have shown that those living in the outer parts travel considerably longer by motorized means of transportation, compared to the residents of inner and central parts of the town. The same main pattern has been found in cities as different as Paris (Mogridge 1985a, Fouchier, 1998), London (Mogridge, ibid.), New York and Melbourne (Newman and Kenworthy, 1989), San Fransisco (Schipper et al., 1994), Greater Copenhagen (Hartoft-Nielsen, 2001), Greater Oslo (Næss, Røe and Larsen, 1995; Røe, 1999), Bergen (Duun, 1994), and Trondheim (Synnes, 1990). However, most of these studies have not controlled for the influence from socioeconomic factors, and almost none have taken the attitudes and subjective lifestyles of residents into consideration. In the Frederikshavn study, our aim has been to investigate whether the influences of urban structure still persist when controlling for socioeconomic as well as attitudinal factors. We also wanted to see if these relationships exist equally strong across different subgroups of the population. Finally, we were curious to see if the relationships found between land use and transport in large cities are also present in a small town. Some debaters have claimed that the influence of urban structure on travel behavior is mainly a phenomenon of large cities, and that the patterns of development of smaller towns (where, after all, a considerable part of the European population lives) are less important in this sense.

\section{The Frederikshavn study}

The main part of the study in Frederikshavn was a questionnaire survey in June, 1999 among households living in 11 residential areas, nine of which in the main urban settlement and two in smaller, peripheral settlements. In addition to the survey investigations, qualitative interviews were made with six households in their homes. Three of these households live in the center of the town ${ }^{1}$ and three in one of the two satellite settlements ${ }^{2}$. Figure 1 shows the approximate location of the 11 residential areas. The survey included questions about travel activities, a number of socioeconomic characteristics of the respondents, leisure interests and shopping preferences, and attitudes to mobility, means of transportation, and environmental issues. In addition, we asked about the household's vehicles and their driving distances (which were to be registered by noting the mileage at the beginning of the period and again at the end of the period a week later). ${ }^{3}$

The persons participating in the qualitative interviews represented a broad variation of occupations, including an assistant social worker, a clerical assistant, a nursing assistant, a trainee teacher, a shipyard workman, two carpenters, two teachers, a chief archivist and a chief secondary school administrator.

In addition to the information provided through the questionnaires and the qualitative interviews, a number of urban structural characteristics have been registered and measured, based on maps, archival statistical data and our own visits in the areas. Statistical analyses have been carried out with the individual respondents as well as with the households as units. Due to the high similarity between the results from the household-level and the individuallevel analyses, the following presentation will mostly deal with the latter set of data. 


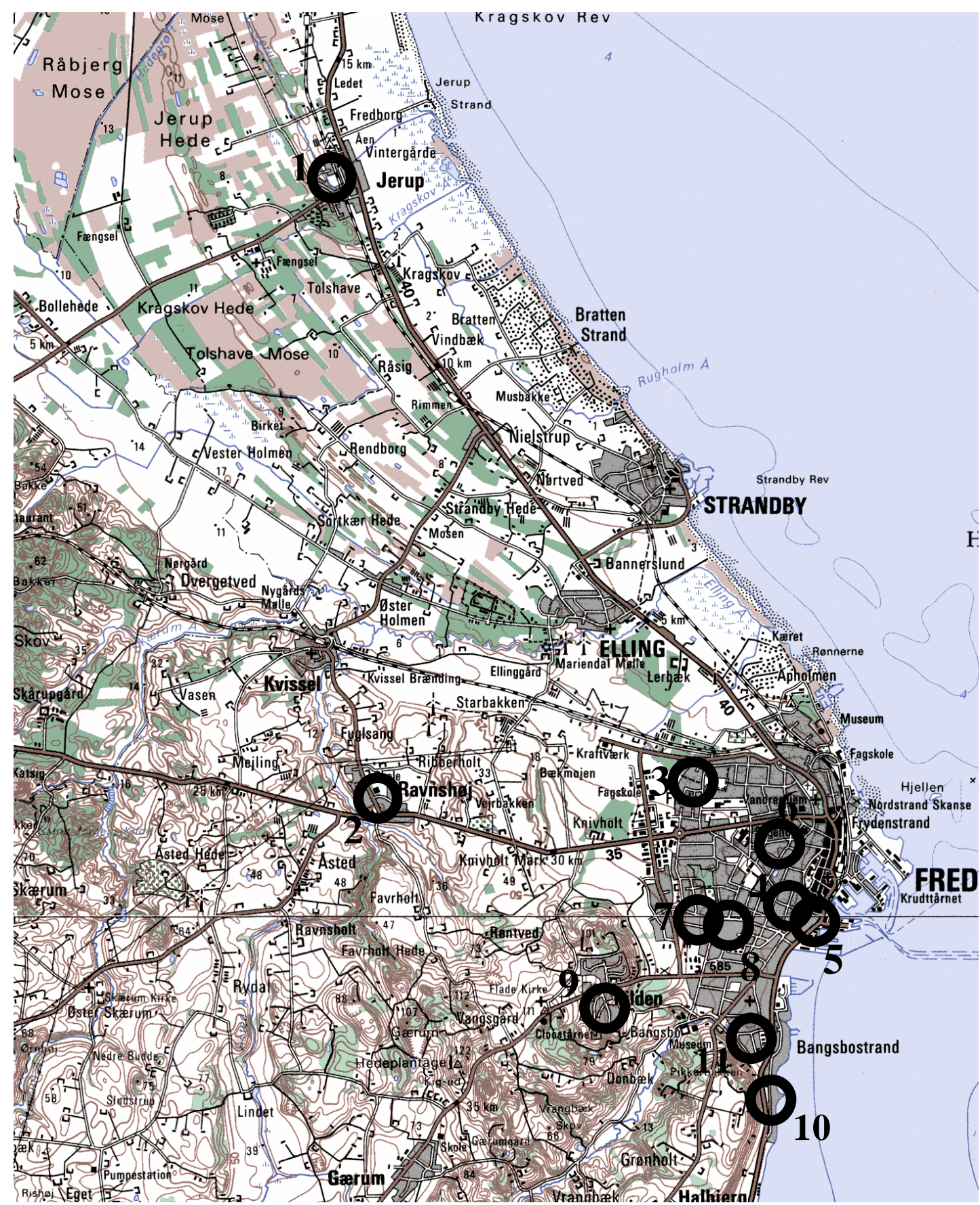

Figure 1

The location of the 11 residential areas. Scale: Approx. 1/110 000.

Results from the quantitative analysis

As mentioned earlier in the paper, investigations in a number of cities have shown a clear relationship between the distance from the dwelling to the urban center and the travel activities of residents. Simple scatterplots of averages for each of the 11 investigated residential areas indicate that such a relationship is present also in such a small town as Frederikshavn, both regarding the total travel distance, travel distance by car, and the proportions of the distance traveled by car and non-motorized modes. 
Figure 2 shows arithmetic means and median values for total travel distance (to the left) and the proportion of distance traveled by non-motorized modes (to the right), with the investigated areas placed along the horizontal axis according to their distance from the center of Frederikshavn. In all these averages, respondents without a driver's license and respondents using their car for official trips more than 10 times a month have been excluded. The relationship between the distance from the town center and travel behavior does not appear to be linear. In the statistical analyses the distance from residence to the urban center has been transformed by means of a hyperbolic tangential function with its turning point at a distance of $3 \mathrm{~km}$ from the center. Such a curve might mirror a situation where the accessibility to relevant facilities decreases from a high level in the central area to a low level in the outer suburbs, where only the most elementary facilities are available, with no further decrease when moving further away from downtown.

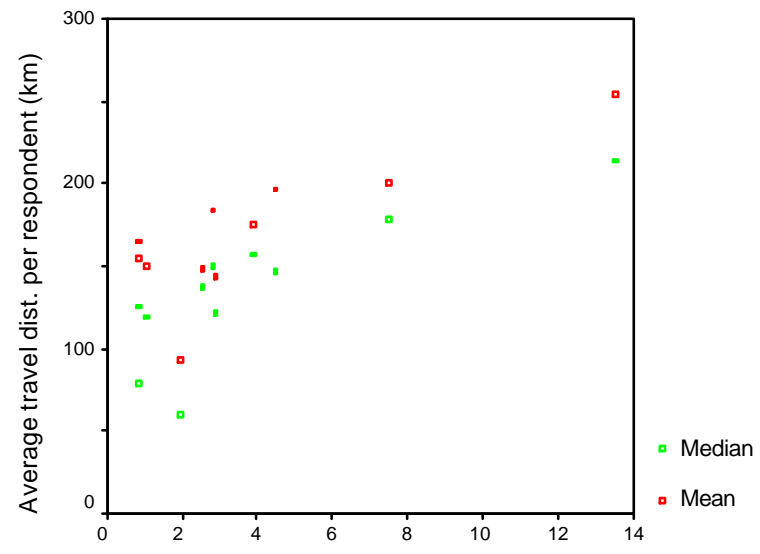

Dist. from residential area to town center $(\mathrm{km})$

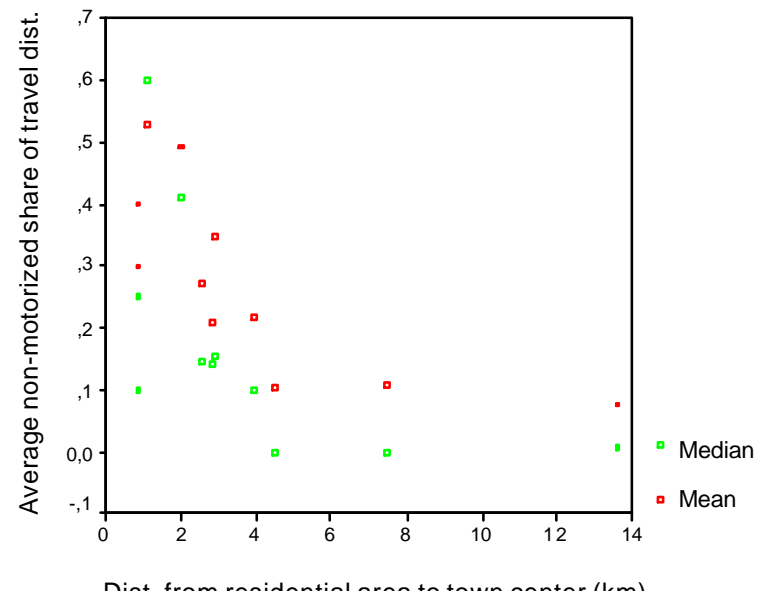

Dist. from residential area to town center $(\mathrm{km})$

Figure 2

Mean and median values for total travel distance (to the left) and the proportion of distance traveled by nonmotorized modes (to the right) among respondents from residential areas located in varying distances from the center of Frederikshavn. Respondents without a driver's license and respondents using their car for official trips more than 10 times a month not included. $\mathrm{N}=11$ residential areas including 375 counting respondents, min. 21 and max. 70 in the separate areas.

Although respondents with outlying travel distances have been excluded ${ }^{5}$, respondents having traveled considerably longer than the average exert a strong influence on the results of the linear regressions analyses. Replacing the ordinary travel distances with the logarithms of the distances traveled reduces the influence of the longest travel distances, which may to a high extent be a result of accidental circumstances. Thus, such a transformation of the dependent variable reduces the scope for accidental variation and may provide a better picture of the factors influencing the more routine transport. ${ }^{6}$

Based on multivariate analyses with logarithmic travel distances, Figure 3 shows the relationship between the total distance traveled by the individual respondents during the week, and the distance from their dwelling to the center of Frederikshavn. In this analysis, as well as in the other analyses of factors influencing travel behavior, the following independent variables were included in the regression: Hyperbolic tangent to the distance from residence to the center of Frederikshavn, public transport provision near the residence, sex, age, number of household members below 18 years, number of years of education, employment, whether the respondent is a student, personal income, driving license, use of car for official trips, responsibility for regular transportation of children, number of days at the workplace or 
school during the investigated week, attitudes to transportation issues, attitudes to environmental issues, and preferences for leisure activities. Of all these variables, the location of the dwelling relative to the town center turned out to have the strongest influence on the travel distance (cf. Table 1).

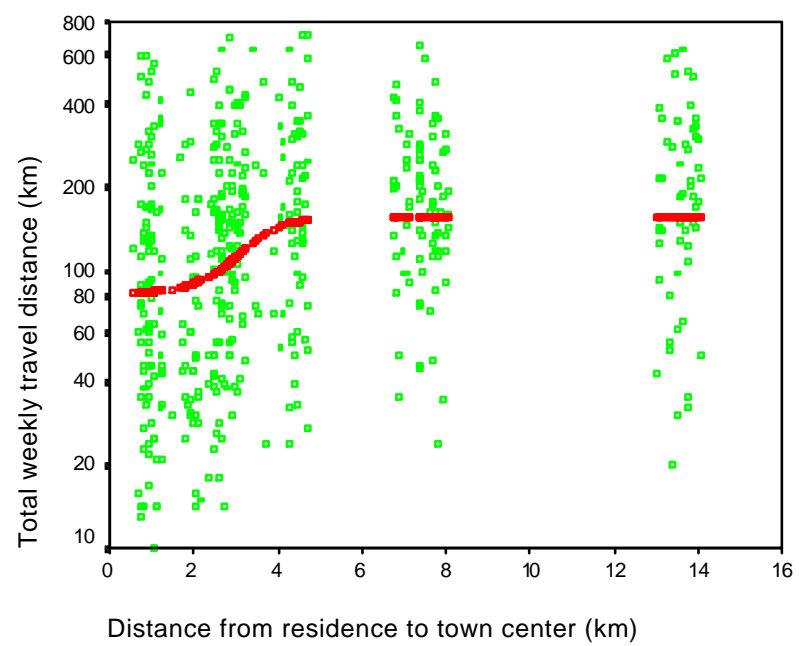

Figure 3

Total weekly travel distance $(\mathrm{km})$ among respondents living i different distances from the center of Frederikshavn $(\mathrm{km})$.

$\mathrm{N}=453$. The regression curve for the controlled relationship between travel distance and the distance between the residence and the town center is shown in red, based on a regression model where travel distances have been measured in logarithmic values, cf. Table 1 . Sig. $=0.000$. Ten respondents with travel distances less than $10 \mathrm{~km}$ are not shown in the diagram.

Table 1: Results from a multivariate analysis of the influence from various independent variables on the logarithm of the total travel distance $(\mathrm{km})$ during the week of investigation. Only variables with a level of significance of 0.15 or lower are included. $\mathrm{N}=453$. Power of explanation (adjusted $\mathrm{R}^{2}$ ): 0.281.

\begin{tabular}{|l|c|c|c|}
\hline & $\begin{array}{c}\text { Unstandardized } \\
\text { regression } \\
\text { coefficient (B) }\end{array}$ & $\begin{array}{c}\text { Standardized } \\
\text { regression } \\
\text { coefficient } \\
\text { (Beta) }\end{array}$ & $\begin{array}{c}\text { Level of } \\
\text { significance }\end{array}$ \\
\hline $\begin{array}{l}\text { Hyperbolic tangent to the distance in km along the road network } \\
\text { between residence and town center (turning point at a distance } \\
\text { from the center of 3 km) }\end{array}$ & 0.137 & 0.240 & 0.000 \\
\hline $\begin{array}{l}\text { Driver's license for car (has driver's license =1, does not have } \\
\text { driver's license = 0) }\end{array}$ & 0.247 & 0.193 & 0.000 \\
\hline $\begin{array}{l}\text { Index for domestic or non-domestic preferences for leisure } \\
\text { activities and shopping (non-domestic preferences = high value) }\end{array}$ & 0.0166 & 0.160 & 0.000 \\
\hline $\begin{array}{l}\text { Number of cars per adult member of the household } \\
\text { Use of private car for official trips at least 10 days a month }\end{array}$ & 0.219 & 0.154 & 0.001 \\
\hline $\begin{array}{l}\text { Index for environmental attitudes (high emphasis on } \\
\text { environmental protection = high value) }\end{array}$ & -0.0200 & -0.121 & 0.003 \\
\hline Sex (female = 1, male =0) & -0.0879 & -0.095 & 0.020 \\
\hline Student (being a student =1, not being a student =0) & 0.112 & 0.064 & 0.122 \\
\hline Constant & 1.800 & & 0.000 \\
\hline
\end{tabular}


As can be seen from Figure 3, the travel distance changes little within the 1 to $1.5 \mathrm{~km}$ closest to the town center. Moving further outwards, the travel distances rise sharply until some 5 kilometers away from the center, whereupon the curve levels off. When controlling for the other independent variables with a level of significance of 0.15 or lower, the weekly distance traveled increases from $84 \mathrm{~km}$ close to the town center to $156 \mathrm{~km}$ when the distance to the center exceeds $5 \mathrm{~km}$. These figures are based on the analysis with logarithmic travel distances $^{7}$. From Figure 3 we can also see that there is a large individual variation in travel distances among respondents living in thee same distance from the city center. This reflects socioeconomic and lifestyle differences, as well as sheer chance, such as the choice of a respondent to vis it his aunt in a city $200 \mathrm{~km}$ away during the week of investigation instead of another week. The adjusted R square figure indicates that $28 \%$ of the variation in travel distance can be accounted for by the investigated variables. For a study covering all travel purposes during a one-week period, this must be considered a fairly high power of explanation. The significance level of 0.000 also indicates that it is highly unlikely that the relationship between location and travel distance found among our respondents could occur by accidence.

Apart from the location of the residence, weekly traveling distances are influenced by driver's license, preferences for leisure facilities and shopping, official trips by car, environmental attitudes, sex, and whether the respondent is a student (see Table 1). None of these effects are surprising. Car ownership and holding a driver's license makes you more mobile and the effects of these variables are in line with findings from numerous previous studies. For persons frequently using the car for official trips, such trips will probably make up a considerable share and contribute to a high amount of total traveling. Also the effects of the two attitudinal variables are in line with expectations. Preference for non-domestic leisure activities and shopping where commodities are cheapest rather than at the closest store contributes to increase the traveling distance, whereas a high concern for environmentalism has the opposite effect. Along with a number of other studies, our data show that being a male contributes somewhat to increase the amount of traveling. The same applies to being a student. The latter effect is probably due to the fact that some of the students travel one or more of the weekdays to the university or other educational establishments in the region center city of Aalborg.

Our material also shows that the respondents' choice of mode of transportation is affected by the location of the dwelling. Non-motorized modes account for a considerably higher share of the total distance traveled by residents of the central parts of Frederikshavn than what is the case among those who live in the outskirts of the built-up area or in the satellite settlements. This can be seen in Figure 6. Similar to Figure 5, the regression curve has been controlled for other variables influencing the modal share with a significance level of 0.15 or lower. Walking and biking could be expected to account for 38 per cent of the distance traveled by a dweller of the central area of Frederikshavn, as compared to only 15 per cent when the distance to downtown exceeds 5 kilometers. In these figures, respondents with extreme weekly traveling distances have been omitted. If those respondents had also been included, the average shares of non-motorized transport would have been lower, but the shape of the curve would be similar. In addition to the effect of a central residential location, the following characteristics were (not surprisingly) found to contribute to increase the share of nonmotorized transport: A low car ownership, transport attitudes not oriented towards the car, no driver's license, staying frequently at the workplace or school, and not being a frequent user of car for official trips. Apart from the effect of going frequently to workplace or school, all these effects are in line with expectations. The latter effect may perhaps reflect a tendency 
among part-time workers and people outside the workforce to utilize a less scheduled week to make more frequent leisure, shopping or visit trips by car.

The proportion of distance traveled by car shows a similar relationship with residential location as for the share of non-motorized transport, but with the highest proportions of car travel among residents of the peripheral areas. Keeping the other variables constant at mean values, a resident living more than $5 \mathrm{~km}$ away from the town center could be expected to travel 77 per cent of the weekly distance by car, as compared to 54 per cent for a resident of the central area.

Public transport plays a modest role for local transport in Frederikshavn. On average for the respondents, public transport (mainly bus, and in a few cases train) accounts for only 5 per cent of the traveling distance. Within the main urban settlement, distances are short enough that the bike most often appears as a more relevant alternative to the car than going by bus. Non of the urban structural factors, including the public transport provision near the residence, appear to exert any influence worth mentioning on the share of the public transport mode. This is true also if we make separate analyses of the three residential areas located furthest away from the town center. From theoretical considerations, one might expect public transport to be more competitive in these areas, as they are located so far away from a number of facilities that the non-motorized modes are less attractive.

Consistent with our findings about the influence of residential location on the total travel distance and the proportion traveled by car, we see a clear effect of the location of the dwelling on the weekly distance traveled by car as well as on energy use for transport. Based on logarithmic travel distances, our analyses show a difference in predicted travel distance by car of $65 \mathrm{~km}$ between a resident in the central area and a person living more than 5 kilometers from the town center. In these figures, the effects of the other investigated variables have been adjusted for. The corresponding differential in estimated weekly energy use for transport is 36 kWh. ${ }^{8}$

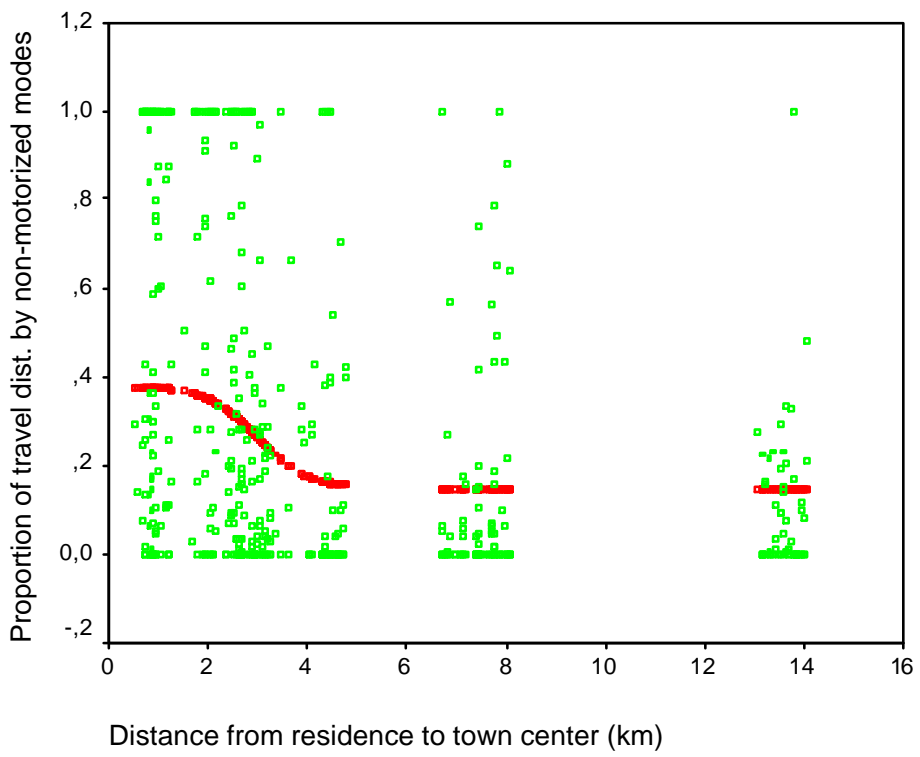

Figure 4

Proportion of total distance traveled by non-motorized modes among respondents living i different distances from the center of Frederikshavn $(\mathrm{km})$.

$\mathrm{N}=448$. Sig. $=0.000$. The regression curve for the controlled relationship between travel distance and the distance between the residence and the town center is shown in red. 
The above findings from the analyses with individual households as respondents are highly consistent with our analyses with households as units, where more accurate measurements of the vehicle kilometers of cars and other private motor vehicles could be used, and where a distinction between local and non-local trips were made.

The accessibility to workplaces and various types of facilities is strongly related to whether the residence has a central or peripheral location. Controlling for socioeconomic and attitudinal factors, the average one-way commuting distance of workforce participants is 4 kilometers longer among respondents living more than 5 kilometers from downtown, compared to their central-city counterparts ${ }^{9}(\mathrm{Sig} .=0,000)$. Of all the investigated variables, the location of the residence relative to downtown is by far the most influential variable affecting the commuting distance.

Due to high multicollinearity, local area density or variables measuring the accessibility from the residence to various facilities could not be included in the same regression models as the location of the dwelling relative to the town center. Separate analyses were carried out where the accessibility variables, or indices based on groups of such variables, were replacing the location of the dwelling relative to the town center. Table 2 shows the standardized regression coefficients and significance levels of these analyses of the urban structural variables' effects on traveling distances (non-logarithmic), as well as the adjusted $\mathrm{R}^{2}$ values of the respective regression models. The accessibility indices were then found to influence the transportation activity variables (except the share of public transport), but the effects were not as strong as the effect of location of the dwelling relative to the town center, and the power of explanation was lower. The same applies to the population density of the residential area when this variable was included in the regression instead of the location of the dwelling relative to the town center.

Table 2: Results from separate analyses where the location of the dwelling relative to the town center has been replaced by accessibility variables or indices. Dependent variable: weekly travel distance (non-logarithmic).

\begin{tabular}{|l|c|c|c|}
\hline & $\begin{array}{c}\text { Standardized } \\
\text { regression } \\
\text { coefficient } \\
\text { (Beta) }\end{array}$ & $\begin{array}{c}\text { Level of } \\
\text { significance }\end{array}$ & $\begin{array}{c}\text { Power of expla- } \\
\left.\text { nation (adj. } \mathrm{R}^{2}\right) \\
\text { for the entire } \\
\text { regression } \\
\text { model }\end{array}$ \\
\hline $\begin{array}{l}\text { Hyperbolic tangent to the distance in km along the road network } \\
\text { between residence and town center (the basic analysis). N =453 }\end{array}$ & 0.228 & 0.000 & 0.192 \\
\hline $\begin{array}{l}\text { Population density in the residential area (residents per hectare, } \\
\text { one mixed-use area has been omitted ). N = 417 }\end{array}$ & -0.164 & 0.001 & 0.171 \\
\hline $\begin{array}{l}\text { Index for the total accessibility from the dwelling to service } \\
\text { facilit ies. N }=443\end{array}$ & -0.132 & 0.004 & 0.173 \\
\hline $\begin{array}{l}\text { Index for the accessibility from the dwelling to shopping } \\
\text { facilities. N }=443\end{array}$ & -0.129 & 0.005 & 0.173 \\
\hline
\end{tabular}

Thus, the location of the residence relative to the town center emerges as a key factor influencing a range of urban structural factors at a more detailed level, all of which influencing the residents' need for transportation: accessibility to workplaces, local administration, shopping opportunities, leisure activities and schools and kindergartens. In order to illustrate the most important relationships between the various independent variables and how these variables in their turn influence travel behavior, a causal model of variables directly or indirectly influencing travel distances by car is showed in Figure 5, based on path analyses. 
Figure 5

Causal model of variables influencing the respondents' travel distances by car during the investigated week (measured with logarithmic values). The strengths of the direct effects of the various independent variable are indicated by the boldness of the arrows.

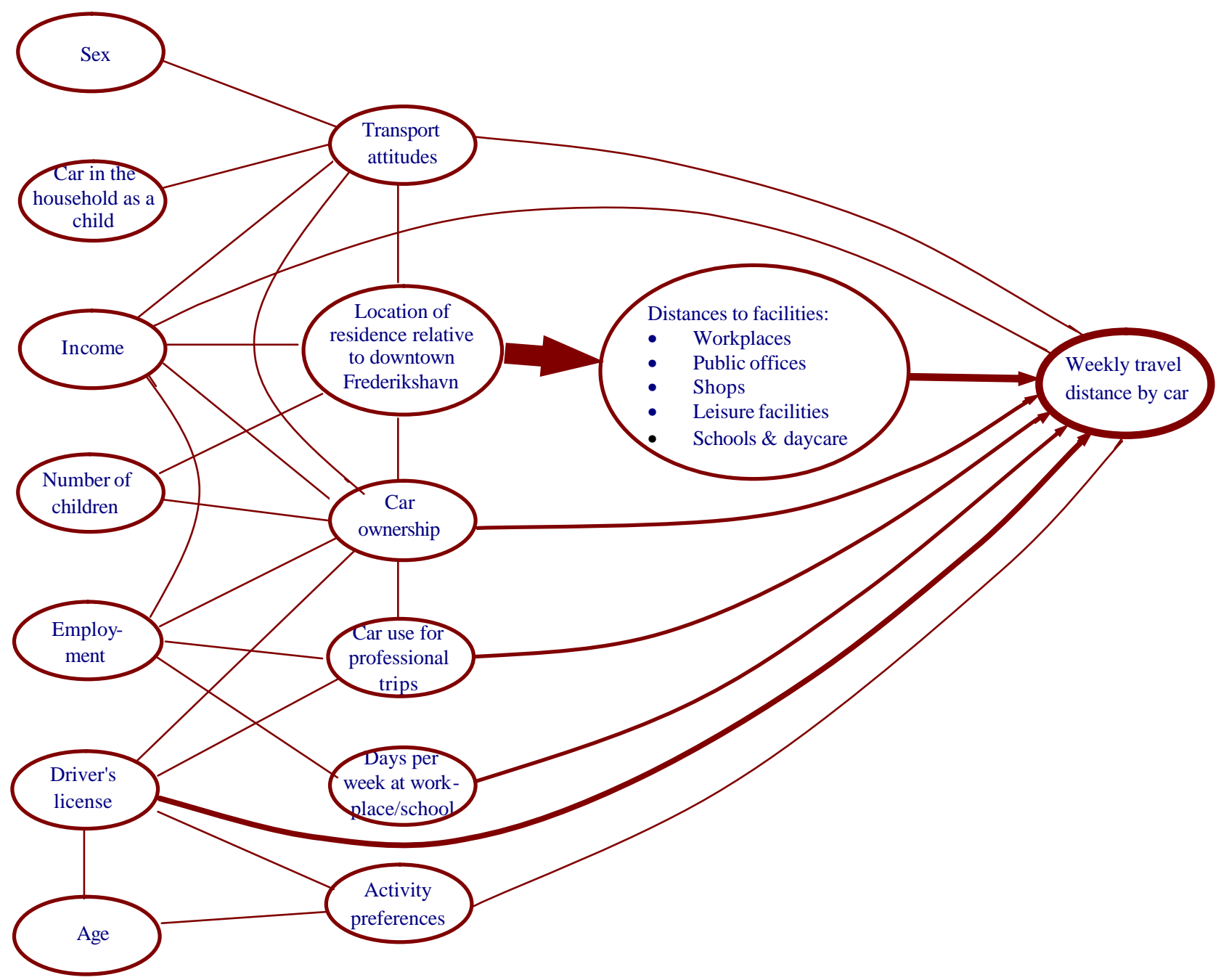


Apart from the influences of the location of the residence, the following characteristics of the respondents contribute indirectly to some increase in the weekly distance traveled by car: Being a male; having grown up in a car-owning household; earning a high income; belonging to a household with children; being close to 45 years of age; and holding a driver's license.

In all our analyses, car ownership has been included among the control variables. Differences in traveling distances and modal split due to different car ownership levels in central and peripheral areas have thus been subtracted from the differences in transport activity that would otherwise have resulted from the analyses. However, this may in fact imply an "overcontrol", as car ownership is itself influenced by the need for motorized transport in order to reach daily activities. Since a wide range of demographic and socioeconomic variables have already been included in the regression model, the remaining difference in car ownership rates between central and peripheral areas is arguably caused by the different availability of workplaces and other facilities in the proximity of the dwelling. The qualitative interviews show examples of such a mechanism. If this holds true among the respondents in general, an analysis without car ownership included among the independent variables would yield a more realistic estimate of the effect of residential location on travel behavior. Carrying out the analysis this way, the effects of residential location on traveling distance and the proportion of non-motorized transport are 16 and 32 percent higher, respectively. The results of our ordinary analyses must therefore be considered conservative estimates of the impacts of residential location on travel behavior.

\section{Differences between subgroups of the population}

The statistical relationships of residential location with total traveling distance, traveling distance, the proportion of distances traveled by car and by non- motorized modes, as well as with energy use for transport are distinct also when splitting our sample into subgroups according to demography, socioeconomic status or attitudes ${ }^{11}$. The most important exception found is among female employees with working-class occupations. Among this group, the traveling patterns appear to be less influenced by urban structural conditions than among the remaining respondents. A possible explanation could be that these women are to a higher extent than other population groups compelled to choose among the job opportunities available in the local area. At the same time, this group of women is often without a specialized education, and hence less dependent on finding other types of jobs than those available in the local community. (Jørgensen, 1992.)

Table 3: Differences between residents living $5 \mathrm{~km}$ away from the town center and residents living in downtown Frederikshavn in average weekly traveling distances. Results of multivariate analyses among selected subgroups of residents, controlling for demographic, socioeconomic and attitudinal variables.

\begin{tabular}{|c|c|c|}
\hline & \multicolumn{2}{|c|}{$\begin{array}{c}\text { Difference between residents of peripheral and } \\
\text { central areas in: }\end{array}$} \\
\hline & $\begin{array}{c}\text { Estimated weekly travel } \\
\text { distance }\end{array}$ & \begin{tabular}{|c|} 
Estimated modal split \\
(percentage points \\
difference in the share of \\
motorized modes) \\
\end{tabular} \\
\hline All respondents $(\mathrm{N}=453)$ & $83 \mathrm{~km}($ sig. $=0.000)$ & $23 \%$ (sig. $=0.000)$ \\
\hline High-income respondents $(\mathrm{N}=114)$ & $125 \mathrm{~km}(\mathrm{sig} .=0.000)$ & $28 \%$ (sig. $=0.000)$ \\
\hline Medium-income respondents $(\mathrm{N}=188)$ & $35 \mathrm{~km}($ sig. $=0.190)$ & $19 \%$ (sig. $=0.000)$ \\
\hline Low-income respondents $(\mathrm{N}=119)$ & 104 km (sig. $=0.000)$ & $27 \%$ (sig. $=0.000)$ \\
\hline Employed men with middle-class or executive jobs $(\mathrm{N}=75)$ & $96 \mathrm{~km}($ sig. $=0.038)$ & $22 \%$ (sig. $=0.009)$ \\
\hline Employed women with middle-class or executive jobs $(\mathrm{N}=54)$ & $126 \mathrm{~km}($ sig. $=0.001)$ & $43 \%$ (sig. $=0.000)$ \\
\hline Employed working-class men $(\mathrm{N}=71)$ & $102 \mathrm{~km}($ sig. $=0.020)$ & $13 \%$ (sig. $=0.087$ ) \\
\hline Employed working-class women $(\mathrm{N}=78)$ & $-36 \mathrm{~km}(\mathrm{sig} .=0.330)$ & $21 \%$ (sig. $=0.019)$ \\
\hline
\end{tabular}


Table 3 shows the different effects of the location of the residence relative to downtown Frederikshavn on the weekly travel distance among some of the subgroups, compared to the sample as a whole. Apart from the weak effect among working-class women, the location of the residence relative to the urban center was found to influence the transportation variables among all subgroups of respondents. The influence of residential location was stronger than among the total sample within the following subgroups: Females in general; persons in the highest as well as the lowest income and educational level quartiles; persons with children in the household; workforce participants regularly transporting children to school or daycare; employed females in middle class or executive posts; students and pupils; and non-retired persons outside the workforce. The relationships between residential location and transport among the following groups were found to be weaker than the average: Males in general, persons with income or education level in the two middle quartiles, and, as mentioned above, employed working-class females.

Distinct from findings in the larger cities of Copenhagen (Næss, 2002) Aalborg (Nielsen, 2002) and Gävle (Tillberg, 2001) we do not find any tendency that households managing on a small everyday amount of transportation make longer and more polluting leisure trips, as has been hypothesized by some authors (Vilhelmson, 1990; Kennedy, 1995). Also when controlling for other potential factors of influence, there are no indications that living close to the center of Frederikshavn contributes to more extensive car driving to non-local destinations, more frequent trips out of the county or a higher number of trips by airplane. On the contrary, if any pattern can at all be seen, there is a slight tendency that living in the outskirts of the municipality contributes to somewhat more travel by car to destinations more than $25 \mathrm{~km}$ away from downtown Frederikshavn.

\section{"Frederikshavn Narratives" - results from the qualitative analysis}

A (minor) part of the Frederikshavn study was based on qualitative research interviews. There are three reasons for supplementing with this approach. Firstly, we wanted to use the interviews as a methodological triangulation i.e. to examine whether there would be different results when an alternative method was used. Secondly, we wanted to explore this approach's ability to seek out potential "blind spots" in the study by revealing dimensions of the relation between land use and transport not accessible by means of the survey method. Thirdly, this methodology was brought in as an exploratory dimension.

We consider the qualitative research interviews a vital supplement to the quantitative data. This break with mainstream research within the field of urban transportation studies enables us to substantiate our general findings and penetrate into the nature of the phenomena in question. In this sense we suggest that the interviews represent illustrations of the mechanisms which at the end of the day lead us closer to the general understanding of the relation between travel behavior and urban structure. Thus 'chasing the mechanisms' by use of the qualitative methods adds to the robustness of the overall research findings.

The main findings in the quantitative analysis are confirmed by the qualitative interviews. Five of the six adult interviewees living in the central part of Frederikshavn (i.e. area no. 5 in Figure 1) have their workplaces within 2.5 kilometers distance, and they shop in the immediate vicinity of the residence. Distinct from this, five of the six adult household members living in the satellite settlement (shown as area no. 2 in Figure 1) have to travel at least $7 \mathrm{~km}$ to reach their jobs, and shopping takes place $4.5 \mathrm{~km}$ or more away from home. Two of the families of the central area have previously lived in satellite settlements, 8 and 13 
kilometers from the town center. Asked about the main reason for moving to the town center, both immediately pointed to the advantage of not having to depend on so much transportation to reach daily activities.
"The reason [for moving] was solely that my job - as a leader of the municipal secondary school - that I had to commute to and from four or five times a day, even though there is 13 kilometers each direction. ... As a leader I have an administrative responsibility, but apart from this there are activities in the afternoon in the secondary school, with classes in the evening as well, and if there were meetings in between, I am sure you can figure out that there would be some kilometers. ... When we moved here, we discovered that the gasoline bill had dropped by DKK 500 a month."
His wife, a 53 year old assistant nurse:
"Besides - although you drove all these times - then you also had a wife, who had to travel. And we have only one car, so it was - who of us is to take the train? Because we do not start working at the same time in the morning. I start at seven and he does at eight o'clock. ... Now we don't need to discuss who is going to have the car, because each of us has only five minutes to the workplace, so everything has become easier."

Two of the three interviewee households presently living in a satellite settlement $7 \mathrm{~km}$ to the west of the town center used their car for most traveling purposes. The members of the third family were eager cyclists and normally used their bikes both for the journey to work and for shopping (which was mostly carried out on the way home from work). For this family, the provision of cycle tracks along the road to the town center was crucial. Without this infrastructure, they would not have settled in this neighborhood.

The wife, a clerical assistant 38 years of age:

"The cycle track is an important reason why we live out in this place. When we were looking for a place to live, we also considered Kilden [another peripheral area ${ }^{12}$ ], where there was a view to the sea. But even for the smallest shopping or for children to get to school, you had to travel down that hill."

Her husband, a 38 year old carpenter:

"If it had been necessary to cycle on the main road, then I would not go by bike."

The wife:

"Then we would never have moved to this place."

This family was quite atypical for their neighborhood, although some of the other residents also used to go by bike. However, among those outer-area residents who for health or environmental reasons prefer cycling to driving in spite of the long journey to work, the provision of a good cycle track has facilitated the replacement of several vehicle kilometers of car traffic each day. On the other hand, there is no indication in the statistical material that the more detailed design of the streets and paths within the residential area (degree of traffic separation and differentiation, cul-de-sacs versus thoroughfares) has any influence worth noticing on the residents' choice of travel mode.

Judged from the interviews, the location of the dwelling seldom prevents people from engaging in the activities in which they are interested. At least, this is true for the majority of households who own at least one car. For those without a car, living far from relevant destinations is more troublesome. In particular, this is true if you are not physically well fit. A woman of the peripheral area who had gotten her vigor reduced from disease, had the following answer to our question about what the car meant to her: 
"Everything. I would feel imprisoned if I had not got the car. Our buses do not go on Saturdays or Sundays."

(Female teacher, 56 years.)

A third interviewee from this area found it necessary to buy an additional car after having moved from a residence relatively close to the center because it became too troublesome to reach daily activities with only one car when living on the periphery. In particular, this was the case for journeys to work, as the public transport services in the residential area were poor. The problem is, according to this interviewee, that no matter where one is bound there will be no matching bus line:

“It doesn't really work with buses either since you will run the risk of getting to work a quarter of an hour or half an hour past ... and then the bus has left, and then you can't get home ... and in the weekends there are no buses either going from here [the residential area] ... so we have to have vehicles"

(Male unskilled worker, 53 years)

All the interviewees seem to agree that collective transportation does not play any major role in the structuring of everyday life transportation in Frederikshavn. Obviously, the provision of public transport will always be subject to multiple demands and requirements. However, in a small town like Frederikshavn, the population base for intra-urban public transport is low. Accordingly, the public authorities' interest in further investments into collective transport will also be low.

By asking the interviewees of what sort of positive qualities they value most we get a picture of what sort of relation between residential location and urban structure residents of Frederikshavn find ideal. The interviewees are aware that they travel less if they have the most frequently used facilities within reach (e.g. work and consumption facilities), but they also enjoy the closeness to the rural hinterland and the experiences of nature. Among the majority of interviewees who engage in outdoor recreation activities, not being located near both of these types of facilities will necessarily generate transport. As we find in the quantitative results, the leisure oriented facilities (i.e. woods for nature experiences) are still the least important facilities to be located near to in terms of lowering the transportation. Location close to work and consumption facilities will have the biggest effect in decreasing the amount of transport.

In the qualitative research material we also asked about the meaning of the "urban atmosphere". By posing this question we get to know how the interviewees perceive the "good urban environment". As these quotes reveal the main characteristics of what the urban atmosphere is all about is framed by the concepts of centrality, density and flexibility:

"Here where we live you can take your bike. If you go 10 minutes in one direction you are in the woods, if you go 10 minutes in the other direction you are at the beach" (Female social worker, 39 years)

"You can go at the library - you can go in Brugsen [shopping center] - you can go to Føtex [shopping center] or at least take your bike. That is it ... and then this neighborhood ... that shows it is part of the city center. It can be called "little Frederikshavn" ...there is no longer than you can use your bike or walk" (Male Archive leader, 42 years) 
Here the specific urban fabric of Frederikshavn evidently plays a major role in this experience. However, also larger urban settlements could strive to achieve an urban morphology where there are green fields within reach from inner-city residential areas. In fact, such green wedges are not only part of the "classic" legacy of urban planning but also known as the doctrine behind the "green fingers" of the Danish capital Copenhagen.

Thus, the "urban quality" of centrality and functional density is considered by the interviewees as important advantages of residential location near the urban center. This evaluation fits the picture from the quantitative part of the study - residential proximity to an urban center with many functions decreases the need to travel in everyday life.

\section{Conclusions}

The Frederikshavn study shows that urban structural variables influence the inhabitants' amount of transport and their choice of means of conveyance also in a small Danish town of around 30000 inhabitants. As one might expect, socioeconomic factors (in particular, driver's license, car ownership and use of car for official trips) and the respondents' attitudes (in particular attitudes to transportation, but to some extent also environment al attitudes and leisure activity preferences) play a role for the respondents' traveling patterns. But also when controlling for these factors and a range of other potential explanatory variables, we find clear relationships between urban structural characteristics and travel activity ${ }^{13}$. The location of the residence relative to the town center is a key factor influencing the accessibility to a number of facility types: civil service, shopping opportunities, higher-level schools, most types of leisure opportunities, and, not the least, workplaces, particularly in the service sector. The proximity or remoteness of these facilities from the residence has a strong influence on the distances needed to reach daily or weekly destinations.

Some of the debaters who claim that proximity or distance has lost its importance seem to confuse the importance to people's choices of activities, the importance to their choices of the locations in which the activities take place, and the importance in term of the traveling carried out in order to reach the chosen destinations. While it may be true that most modern people are less tied to local places than previous generations (although this varies considerably among population groups), and hence engage in activities and utilize facilities more or less independently of what is available in the neighborhood of the residence, this does not mean that the location of urban functions has lost its importance to the amount of transport carried out in order to reach these destinations. On the contrary, the less people limit their choices of destinations (e.g. workplaces, schools, shops and leisure facilities) to what is available locally, the more will the amount of transport carried out be influenced by the location of the residence in relation to the city- level pattern of such facilities.

Our finding about the influence of residential location on travel behavior is in line with conclusions from investigations in a number of cities in Scandinavia as well as in a wider international context. In spite of such evidence, it is still common among debaters on sustainability and urban form to question whether density and other urban structural factors really have any influence worth mentioning on transportation's energy use and emissions (e. g., Breheny, 1992; Frey, 1999; Williams, Burton and Jenks, 1999). Frequently, however, such conclusions stem from model simulations where the results may simply reflect that the assumptions of the model do not capture the actual influence of the urban structure on travel behavior (see, e.g., Dasgupta, 1994; Simmonds and Coombe, 1999). In other cases, the lack of relationship between urban form and transport is the outcome of studies not including the 
variables that could from theoretical considerations be expected to have the strongest influence on each other. For example, some studies have focused on trip frequency (among others. Kitamura et al., 1997; Boarnet and Sarmiento, 1998) or travel time (Gordon and Richardson, 1997; Snellen et al., 1998) as transportation activity variables, without investigating the influence of urban structure on travel distances or modal split. In some other studies, including Breheny (1995), conclusions are made about an absent or insignificant relationship between urban structure and travel, based on a comparison of travel survey data from towns of varying population size. However, the number of inhabitants is hardly a good indicator in order to test whether urban structure affects travel behavior. Among empirical studies where the influences on travel from urban densities and the location of residences within the urban area have been investigated, the converging conclusion is that dense and concentrated cities do contribute to reduce traveling distances and the use of cars.

Controlling for the other investigated variables, the difference between the central and peripheral locations of Frederikshavn in weekly traveling distances with motorized modes of transport is about $80 \mathrm{~km}$, compared to about $120 \mathrm{~km}$ in Greater Oslo and Greater Copenhagen (Næss, Røe and Larsen 1995, Næss, 2002). Since the distance between center and periphery is much longer in the greater cities of Oslo and Copenhagen, this means that traveling distances increase at a much higher rate per kilometer the distance from residence to downtown increases in Frederikshavn than in the two larger cities. In Frederikshavn, you are already out in the countryside when you are 4 or 5 kilometers away from the city center, while in Oslo and Copenhagen the urban fringe is $20-40 \mathrm{~km}$ away from downtown. In addition, Frederikshavn has a typically monocentric structure, whereas larger cities often have a hierarchy of local centers in addition to the downtown area. In Frederikshavn, the accessibility from the residence to facilities depends mainly on the distance to the town center. In larger cities, the accessibility to facilities is usually determined both by the distance to the downtown area and how the residence is located in relation to local centers.

Developmental patterns that can contribute to reduce the amount of motorized transport in urban areas are highly consistent with housing types favorable in order to limit the need for energy for space heating in buildings. Such urban structures also appear to be favorable when evaluated against a broader set of criteria of an environmentally sustainable urban development (Næss, 2001). Yet, the location of new residences can only influence a modest part of the total energy use in Denmark. In order to achieve improvements that can really help reducing the national contribution to global environmental problems, a much broader range of strategies and measures will be called for. However, within such a broad effort, urban planning could play an important part.

\section{References}

BEIMBORN, E. (1979): Transportation and Public Facilities Planning. In Catanese, A. J. \& Snyder, J. S. (eds.): Introduction to Urban Planning, pp. 259 - 279. New York: McGraw Hill.

BOARNET, M. and SARMIENTO, S. (1998) Can Land-use Policy Really Affect Travel Behaviour? A Study of the Link between Non-work Travel and Land-use Characteristics. Urban Studies, 35, pp. 1155-1169.

BREHENY, M. (1992) The Contradictions of the Compact City: A Review, in M. BREHENY (Ed.): Sustainable Development and Urban Form pp. 138 - 159. London: Pion Limited.

BREHENY, M. (1995) The compact city and transport energy consumption. Transactions of the Institute of British Geographers NS 20, pp. 81 - 101.

CHRISTAlleR, W. (1933/1966): Central Places in Southern Germany. Englewood Cliffs, NJ: Prentice-Hall, 1966. (Translation of "Die Zentralen Orte in Süddeutschland", published in 1933.)

DASGUPTA, M. (1994) Urban travel demand and policy impacts. Paper presented at the course "The urban environment and transport policy” at the Norwegian Institute of Technology, Trondheim, 10 - 12 
January 1994

DUUN, H. P. (1994) Byutviklingens transportvirkninger. En studie av transporteffekter, energibruk og utslipp til luft ved alternative byutviklingsstrategier i Bergen. (The transportation effects of urban development. A study of transportation effects, energy use and emission to the air from different urban development strategies in Bergen) Bergen: West Norwegian Planning Group

FOUCHIER, V. (1998) Urban density and mobility in Ile-de France Region. Paper presented at The UN-ECE $8^{\text {th }}$ conference on Urban and Regional Research, Madrid, 8-11 June 1998.

FREY, H. (1999): Designing the City. Towards a more sustainable urban form. London/New York: E \& FN Spon/Routledge.

GIDDENS, A. (1984) The Constitution of Society. Outline of the Theory of Structuration. Cambridge: Polity Press.

GIDDENS, A. (1991) Modernity and Self-Identity: Self and Society in the Late Modern Age. Oxford: Polity Press.

GORDON, P. and RICHARDSON, H. W. (1997) Are Compact Cities a Desirable Planning Goal? Journal of American Planning Association, 63, pp. 95-106.

HANDY, S. (1996): Methodologies for Exploring the Link between Urban Form and Travel Behavior, Transportation Research D, 1, pp. 151-165.

HARTOFT_NIELSEN, P. (2001): Boliglokalisering and transportadfærd. (Residential location and travel behavior.) Hørsholm: Danish Forest and Landscape Research Institute.

JØRGENSEN, G. (1992): Erhverv i boligkvarteret - en vej til bedre bymiljø? (Business activity in the residential area - a road towards a better urban environment?) Hørsholm: Danish Building Institute.

KENNEDY, M. (1995) Ekologisk stadsplanering i Europa. (Ecological urban planning in Europe.) In: Institutionen för tillämpad miljövetenskap, Göteborgs universitet 1995: Den miljövänliga staden - en utopi?. Rapport från en seminarieserie, pp. 25-31. Gothenburg: University of Gothenburg.

KITAMURA, R.; MOKHTARIAN, P. L. and LAIDET, L. (1997) A micro-analysis of land use and travel in five neighborhoods in the San Fransisco Bay area. Transportation, 24, pp. 125-128.

LINDÉN, A-L. \& CARLSSON-KANYAMA, A. (1998) Dagens livsstilar i framtidens perspektiv, (Todays lifestyles in a future prespective) Lund: Lund University, Department of Sociology, Research Report 1998:4.

NEWMAN, P. W. G. and KENWORTHY, J. R. (1989): Cities and Automobile Dependence. Aldershot: Gower Publications.

NIELSEN, T. A. S. (2002): Boliglokalisering og transport i Aalborg. (Residential location and transport in Aalborg) Ph. D. thesis. Aalborg: Aalborg University.

NÆSS, P, (2001) Urban Planning and Sustainable Development. European Planning Studies, Vol. 9, No. 4, pp. 503-524.

NÆSS, P. (2002) Residential location affects travel behavior - but how and why? Paper for the XVI Aesop Congress in Volos, Greece, July 10-14, 2002.

NÆSS, P. AND JENSEN, O. B. (2002): Urban Land Use, Mobility and Theory of Science - Exploring the potential for Critical Realism in empirical research. Journal of Environmental Policy and Planning, Vol. 4, No. 4..

NÆSS, P. and SAGLIE, I.-L. (2000): Surviving between the threnches: Planning research, methodology and theory of science. European Planning Studies, 8, pp. $529-550$.

NÆSS, P.; RØE, P. G. and LARSEN, S. L. (1995): Travelling Distances, Modal Split and Transportation Energy in Thirty Residential Areas in Oslo. Journal of Environmental Planning and Management, 38, pp. $349-370$.

RØE, P. G. (1999): Romlig-strukturelle forholds betydning for intraurbane hverdagsreiser. (The influence of spatial-structural conditions on intra-urban everyday trips.) Paper presented the Housing and Urban Research Seminar, Institute of Housing Research, Gävle, April 14 - 16, 1999.

SCHIPPER, L.; DEAKIN, E. and SPEARLING, D. (1994): Sustainable Transportation. The Future of the Automobile in an Environmentally Constrained World. Paper presented at a research seminar arranged by the Board of Communications Research, Stockholm, September 23, 1994.

SIMMONDS, D. and COOMBE, D. (1999): The Transport Implications of Alternative Urban Forms, in K. WILlIAMS, E. BURTON, and M. JENKS, (eds.) Achieving Sustainable Urban Form pp. 121 130.

SYNNES, H. (1990): Reisevaner i Trondheim 1990. (Travel habits in Trondheim 1990) M. Sc. dissertation at the Norwegian Institute of Technology, Trondheim.

TILLBERG, K. (2001): Barnfamiljers dagliga fritidsresoer i bilsamhället - ett tidspussel med geografiska og könsmässiga dimensioner. (Daily leisure trips of families with children in car-based society - a time puzzle involving geographical and gender differences.) Doctoral thesis. Uppsala: Uppsala University. 
VATNE, E. (1993): Agglomerasjonsøkonomi and eksternaliteter. Virkninger for økonomisk vekst og territorriell utvikling. SND-report 49/93. Oslo: SND. (Agglomeration economy and externalities. Impacts on economic growth and territorial development.)

VILHELMSON, B. (1990): Vår dagliga rörlighet. Om resandets utveckling, fördelning och gränser. (Our daily mobility. On the development, distribution and limits of traveling) TFB report 1990:16. Stockholm: The Swedish Transportation Research Board.

WILLIAMS, K.; BURTON, E. and JENKS, M. (1999): Achieving Sustainable Urban Form: Conclusions, in K. WILLIAMS, E. BURTON, and M. JENKS, (eds.) Achieving Sustainable Urban Form pp. 347 355.

\section{Notes}

${ }^{1}$ To be more specific, area no. 5 in Figure 1.

${ }^{2}$ I. e. area no. 2 in Figure 1.

${ }^{3}$ The questionnaires were quite extensive, with one set per household member and a requirement to record the traveling distances by different modes for each day of the week, as well as the vehicle mileage at two times. The respondents were also asked to differentiate between trips within and outside the municipality, and between private and official trips. Not surprisingly, then, the overall response rate was only $24 \%$. In total, we received completed questionnaires from 381 households and 628 individuals aged 15 or more. Sample characteristics were compared with statistical data for the municipality as a whole as well as for the census zones among which the residential areas were chosen. This comparison shows that our respondents do not differ much from the municipal population in terms of household size, sex, employment or income. Persons above 45 years make up a somewhat larger part of our sample than in the municipality, but this bias is not serious. Our respondents also include a higher proportion of persons with a long education than in the population at large. In general, still, the sample must be considered fairly well representative for the inhabitants of Frederikshavn. Anyway, because the questionnaire included a number of questions about socioeconomic as well as attitudinal characteristics of the respondents, a statistical control for the influence of these factors could be made in the analyses of the relationship between the urban structural situation of the dwelling and the residents' travel behavior.

${ }^{5}$ In order to reduce the source of error long-distance trips constitute, seen in the relation to the purpose of our analysis, respondents with outlying travel distances (i.e. values larger than 1.5 times the interquartile range above the value of the upper $25^{\text {th }}$ percentile) as car driver, car passenger, train passenger or bus passenger were excluded. Omitted were also persons who did not report any transport at all although they obviously or most likely must have made trips during the week of investigation. Furthermore, respondents who stayed overnight away from home more than three nights during the week were excluded, as their daily activities would to a high extent take place from a base different from the residential address. For the purpose of our analysis, such respondents would be irrelevant.

${ }^{6}$ Actually, we have carried out analyses with the total travel distance, the distance traveled by car and the energy use for transport measured in ordinary kilometers and $\mathrm{kWh}$ as well as by logarithmic values. However, the power of explanation of the investigated variables turned out to be higher when the logarithmic values were used.

${ }^{7}$ If ordinary distances are used, respondents with very long trips exert a stronger influence, and the estimated travel distances increase by about $50 \mathrm{~km}$ in the central as well as in the peripheral areas. The difference between the city center and the outskirts is a little bit larger in the analysis based on non-logarithmic values ( $82 \mathrm{~km}$, as compared to $72 \mathrm{~km}$ in the logarithmic analysis).

${ }^{8}$ When non-logarithmic values are used, the differences are somewhat larger ( $87 \mathrm{~km}$ and $37 \mathrm{kWh}$, respectively).

${ }^{9}$ None of the investigated residential areas are located in the southernmost and southwestern part of the municipality. In order to avoid the bias this might cause, the (quite few) respondents working in these parts of the municipality were omitted from the analysis. Thus, the workplaces included in the analysis were located within the same parts of the municipality as the selected residential areas.

${ }^{11}$ For each subgroup, a separate multivariate analysis was made, with the same control for other investigated variables as in the analyses of the total sample.

${ }^{12}$ Shown as area no. 9 on the map in Figure 1.

${ }^{13}$ Compared to simple, bivariate analyses, the relationships between urban structural variables and travel behavior in our Frederikshavn data become somewhat weaker when controlling for demographic and socioeconomic variables. However, the inclusion of attitudinal variables does not imply a further weakening of these relationships. On the contrary, the relationships between residential location and travel behavior turn out to be slightly stronger when attitudinal variables are included in the multivariate analysis. 